\title{
Ethical Conflict between Pragmatism and Idealism in Arun Joshi's The Apprentice
}

\author{
Amit Kumar \\ Research Scholar (Ph.D.) \\ H N B G University Garhwal \\ Email: amiteng03@gmail.com
}

\begin{abstract}
Joshi has occupied a great place in Indian writing in English Literature. He deals with the inner conflicting predicament of urban Indian society in all his five novels. The Apprentice is distinct from his other novels in its tone, style and theme. The Apprentice deals with the ethical conflict between pragmatism and idealism which traps its protagonist through his conscious action, decision and the reaction of those decisions based on his root and psyche. The protagonist suffers from his inner conflict of idealism and pragmatism which makes him a split personality in a phoney selfish society. Joshi deals with the psychological problems of modern men which make them unable to adjust to society in thirst for material pleasure and worldly values. Ratan Rathor is the main protagonist and narrator of the novel The Apprentice who is the son of a revolutionary patriot full of idealistic values. He finds his inner self grind between the conflict of pragmatism and idealism which creates a painful predicament of restlessness and suffering. He has two conflicting worlds in his inner self of which one idealism deals with the values of life, peace, humanity, selfless service and of another pragmatism deals with lust for material and sensual pleasure where money has all values for its credit.
\end{abstract}

Keywords- Restlessness, Peace, Suffering, Inner Crisis, Trauma

\section{Introduction}

Joshi has portrayed the ethical conflict in his protagonist that centres on idealism and pragmatism. The main protagonist of the novel, Ratan Rather makes a long journey from revolutionary idealism to self-love and superciliousness. He is both the hero and the scoundrel in his fables. Ratan has a double inheritance from his parents which makes him suffer and restless. 


\section{The Creative Launcher | Vol. 6 \& Issue 2 (June, 2021)|94}

As Dr. Arvind M. Nawale rightly remarks, "Ratan is a child of double inheritance- the patriotic and ideal world of his father, and the worldly selfish and sagacious universe of his mother" (Nawale 75). Ratan Rathor's father is a revolutionary patriot who sacrifices his life for his country. He is a lawyer who never thinks about his family and financial needs. Ratan follows the path of his idealistic father which leads towards generosity, decency, purity and humanity. On the other hand, his mother suffers from tuberculosis and feels the horrible predicament of lack of money because she could not get proper treatments. She becomes the worshiper of money. Ratan follows the pragmatic ideology of his mother where money has all values.

\section{Discussion}

Ratan is the narrator-protagonist of the novel who narrates the whole story of his life in a confessional mood to a young NCC cadet. Ratan is only ten years old when this rivalry creates an ethical conflict in his inner self. He finds his inner self split between two different ideologies of idealism and pragmatism. T. J. Abraham rightly remarks, "Ratan's life is a see saw battle between the opposite values represented and propagated by his father and mother" (Abraham 37 38). Since his childhood, he wants to follow his father selfless ideology to serve humanity. Ratan represents the purity of his inner soul, "I believed I was ready to sacrifice all without the promise of reward or of success" (p-25) but his mother never allows him to follow the ideologies of his father which she considers futile and useless. She warns him about the real consequences of his father's idealism, "Don't fool yourself, son. Man without money was a man without worth. Many things were great in life, but the greatest of them all was money" (p.25).

Though his mother leaves him speechless, Ratan still has a strong intention to serve his country altruistically. He becomes determined to accompany Subhas Chandra Bose in National Freedom Movement. His mother becomes worried about his future and asks him, "How would I make a living after the movements were over" (p.23). Ratan profusely wants to execute his altruistic liabilities towards his nation. His mother has a different perspective about their real-life situation who wants sustainable change to come out from their malice condition. She wants to improve their present situation. Therefore, she says, "It was not patriotism but the money that brought respect and brought security. Money made friends. Money succeeded where all else failed. There were many laws, she said, but money was a law unto itself'(p.23). She wants to make him clear about the real and real life situation which considers the value of money and 


\section{The Creative Launcher | Vol. 6 \& Issue 2 (June, 2021)|95}

power. She warns him in a rude way to understand the value of money or to get ready to face the consciences in life one day.

Ratan wants to fight for some ideal situations like his father. He is full of loyalty and of patriotic spirit which makes him excide and lofty like free air. It is after independence, Ratan wants to live in a bright India but it becomes politically Machiavellian, deceitful, tricky and atrocious were "Money was the only God. Then followed a twilight in which what hope was left dwindled. Traitors flourished. Wise men were there but their word went unheeded" (p.68).

In order to reveal the treachery of Indian society, Ratan writes an article on THE CRISIS OF CHARACTER in which he explores the deficiency and covetousness of post-independent urban Indian society but unfortunately it remains unpublished throughout his life. Ratan wants to follow his father's idealism and integrity to be good, respected in society and to be used of humanity for peace and meaning. After his father's death, Ratan anxiously becomes aware of his responsibilities towards his mother and his own future. In his restlessness, he says thinking about his career, "what would happen to me when the college finished? How would I earn a living?" (p.22) Ratan finds himself in a lurch like Sindhi Oberoi in the novel The Foreigner who remains in search of his roots and real existence in urban Indian society. His friend Brigadier and his family prove enough genuine to support him and his family in a troubled situation. Finally, Ratan comes to Delhi with two hundred rupees to peruse his career with his presumption and superciliousness which he finds from his snobbish mother.

Arun Joshi represents the truth of hollow urban Indian society where no one has time for humanity and social welfare. This is why, Professor Prasad has rightly pointed out that, "the novel is both a social document and threnody of a tormented soul” (Kumar 113). Ratan does not find a job and becomes restless, he says "my money was running out, And so was my hope" (p.30). He lives with five poor labour men in the cheapest inn in Delhi among them there are a turner, two Mirzapur brothers, a goldsmith's assistant and a stenographer from Saharanpur. It is his malice situation among those earning boys which makes him realizes the importance of money in life like his mother. Ratan endures the hardship of sluggishness which generates feelings of uncertainty and restlessness. His roomies are working and earning money but he does not get a job in spite of having good education certificates and being a son of the martyr. It accelerates his suffering, "I would leave early because I was trying to cut out the breakfast to 


\section{The Creative Launcher |Vol. 6 \& Issue 2 (June, 2021)|96}

save expenses, and also as an economy measure, I had taken to travel on foot what mileage must I tramped those two months! I must have walked every road of this city" (p.32).

Ratan stimulates the predicament of his tedious misfortune. He concludes to return home which could be a subject of shame and humiliation. He becomes split in his inner conflict which he says. "I began to wonder if there was something drastically wrong with me or my notion of the world" (p.34). As Tapan Kumar Ghosh observes, "Crisis in the soul of an individual, who is entangles in the mess of contemporary life with its confusion of values and moral anarchy and his untiring quest for a remedy lies at the core of Arun Joshi's exploration of human reality in The Apprentice" (Sharma 56).

Ratan's enthusiastic efforts make him adequate to get a job as a clerk in a war purchase department through the help of his roomie stenographer. Joshi portrays the realistic condition of forlorn educated youth who astray in search of a job like Ratan in urban Indian society. Ratan concentrates and works hard devotedly as an apprentice. His loyalty and submissiveness sway his Superintendent. He makes a mark of his own in upper-class society. That's why he leaves the inn without informing anyone even not the stenographer who helps him to get his job. His sorrow and troubles make him change his way to pragmatism. Ratan wants a pleasurable life for which he rejects the ideas of idealism. He renounces his moral and ethical values. In order to become a flourishing officer, Ratan pushes his soul and morality into the abyss of the bourgeois filth of which his father does hate. Ratan's obedience and true devotion to his work generate deep respect and affection in the mind of his Superintendent who makes a deal with him to save his job if he marries his niece. Personally, Ratan is not yet ready to get marry but to save his job and honour, he agrees to get married to his Superintendent's niece. His marriage is not accomplished through any social or religious custom but as a deal. Ratan confesses his inherent pretension which organizes the bond equations in his own ways. He becomes pragmatic like his mother, "If I married his niece I would stay in the job" (p.56).

Joshi consciously portrays the loss and devastation of moral and ethical value in bourgeois modern society which also does not have any emotional and human values. He portrays the inner conflict of his protagonists which split their personality. Their inner conflict makes them rootless, alienated frustrated and restless. It becomes the predicament of their painful suffering. 


\section{The Creative Launcher | Vol. 6 \& Issue 2 (June, 2021)|97}

Ratan, ignoring his idealistic view, saves his job after getting married as a deal but his painful suffering makes him upset and desperate in his modern malice society. Every moment and plan of his life becomes a deal which he says, "Deals, deals, deals my friend that's what the world runs on, what it is all about" (p.59). Though Ratan is frustrated with his present situation but he followers the idealistic path of his father. He denies taking bribe by giving his father's example who takes his last step towards the sergeant's gun and sacrifices him for the sake of his country.

Later, Ratan becomes a part of his corrupt surroundings. It creates disillusionment and inferiority in his inner self. He enters in the worldly wisdom of his mother where he runs behind more and more money and material comforts. He follows his treacherous society and becomes a scoundrel and liar like others as he considers himself not an exceptional case among them. He becomes blindly emotionless and insane to give his career on height to get all worldly comforts. It is during the Indo-china war when Ratan makes a deal with Sheikh an underworld don and his friend Himmant Singh to clear the sub-graded war materials for a huge bribe that could bring him new heights in luxurious modern society.

Ratan sells his moral and ethical values to fill his life with worldly convenience. But he lives in cries of his double inheritance which makes him brusque, self-centred and insensitive towards his moral responsibility. He clears the defective war material without thinking about the lives of innocent people. Ratan goes to Bombay in order to finalize the deal where he expresses his inner fear to Sheikh and Himmat Singh. There Ratan confesses his flourishing enthusiasm towards wine and women which make him debouched and wicked.

Ratan becomes a sycophant in the hand of bourgeois society who uses him for their own profit. He suppresses his inner self in imitation of hollow modern society. He becomes restless and faces the consciences of his oppressed idealistic feelings in the dark web of worldly pleasure. He becomes uncomfortable which he says, "of curse to begin with it was all very vogues I felt only restless, depressed, uncomfortable" (p.16).

He becomes proud and pompous about his luxurious government position. He loses his ethical moral values and becomes uprooted,

I had become vague, indifferent rude. People world come and wait for hours on a filthy bench and I would not call them in Eves through visitor seemed particularly lower class, I would 


\section{The Creative Launcher | Vol. 6 \& Issue 2 (June, 2021)|98}

turn immediately pompous and lose no time in conveying to him the importance of my office and what difficulties he might expect if he failed to take note of it. (p.77)

Ratan becomes a victim of rising corruption in his inner-self. He becomes alien and restless over his flattery and cunning self. He repents his decision when he goes to the hospital to see his friend Himmat Singh who badly injured by several others in war. The drastic scene of the hospital fills Ratan soul with repentance and regret. In his restless, Ratan says, "what had I done, what had I done which I should not have done? What was right, what was wrong? What was the measure for doing things or not doing them? Where were the dividing lines: between success and failure, loyalty and betrayal, love and hate" (p.83).

Through the painful suffering of Ratan Rathor, Arun Joshi portrays the predicament of inner crisis in modern society which split between the good and evils, practical and religious wisdom, and loyalty and betrayal. Joshi psychologically deals with the disillusionment of urban Indian society who unethically runs to possess worldly comforts and forget the present humanity and of Almighty God. In order to make his career brighter, Ratan loses his moral values and inner-self. After this sinful act, he finds himself, "a NOBODY" (p-85) who lives despondently in his imitative life. Ratan realizes his lost self and sees the ashes of his soul. D.R Sharma observes The Apprentice; "as study of loss and the retrieval of one's soul” (Saleem 83).

The unethical deal of damaged war material becomes a curse to him. Ratan becomes the reason for his dearest friend Brigadier's suicide and the death of many other soldiers. It makes his life hollow and purposeless. Ratan astounds over his ethical havoc which ruins his morality and his father's ideology of use to society and nation. He becomes anxious about rootlessness and his real identity. In the fear of his split personality, Ratan concerns his inner distress, "The more money I accumulated the more I was dissatisfied and more I was determined to enjoy life. And all the time I thought death" (p.103).

The superintendent of Police summons Ratan Rathor for interrogation and investigation about the unauthorized supply of sub-grade war material in the army which become the reason for the death of hundreds of lives. Ratan refuses to have any knowledge about this sub-grade war-material scandal. The police and Army Intelligence authorities become fail to prove him guilty in lack of evidence. They threw him behind the bars in suspicion based on their reliable source. In jail, his own spirit tries to show him the difference between good and evil which infuriates Ratan so much that he agrees to prove himself guilty to atone for his sins. Ratan 


\section{The Creative Launcher |Vol. 6 \& Issue $2($ June, 2021)|99}

becomes aware of the hollowness and desolation of pragmatism which he selects to get a higher career. He commemorates his father's idealism and cries in distress, "I cried, sobbed. I cried and beat my head against the sill. Father, I cried, Father, Father, what have I done" (p.160).

He wants to confess his sinister act but finds himself unable to confess in the police station and comes back. He writes his confession to the Superintendent of Police but never gives him. Ratan realizes the most futile discrepancy of his life remains between idealism and pragmatism which makes his life ruined. His idealism recalls him confessing his evil deed of corruption but his pragmatism stops him to reveal the truth. T. Guruprasad connects the two roles of the narration into a single continuum:

It is worthy of critical attention that this novel is also in the confessional mode. As a matter of fact, the narrator in this novel is an insistent confessionalist, confession is a factor in his redemption, for Ratan has got hold of a young man, an apprentice in the urban life of Delhi [...], as his confessor, and he probably means to teach him the crookedness of his world that the youngster is going to enter, or has just entered. (Bhatnagar 21)

Ratan realizes his rootlessness and indifference in his inner soul. After having a deep consideration over his disgraceful act, Ratan determines to resolve his unethical act by wiping the shoes of the congregation. The Bhagavadgita on the other hand recommends humility as the first need for a devotee, "The devotee has a sense of utter humility. In the presence of the Ideal, he feels that he is nothing. God loves meekness, the utter prostration of the self" (Dwivedi 96). By clearing the shoes of the devotees sitting on the steps of the temple on his way to the office, Ratan gets spiritual happiness and a divine way to come out of the repentance of his misdeeds. Ratan says "that I imagine, would be one way of putting it. I would be happy if I could do what I do as best as I can. Without vanity and without expectation and also without cleverness" (p.172). Ratan does not believe in dogmas and idol worship instead like his father, he wants to "Be good. Be decent. Be of use" ( p.171). Ratan narrates his harsh and painful experiences to an innocent young boy to know the reality of this phantom world. Ratan represents the reality of his hearty repentance through the true and genuine description of his immoral and vile act. Throughout his life, Ratan faces the crisis of idealism and pragmatism in his inner soul in which idealism wins over the worldly values of pragmatism. Indira Bhatt and Suja Alexander rightly remark, "Ratan 


\section{The Creative Launcher | Vol. 6 \& Issue 2 (June, 2021)| 100}

in The Apprentice believes there is God and seeks salvation for his sin by serving mankind" (Bhatt and Alexander 69).

\section{Conclusion}

The title of this novel suggests the whole meaning of Ratan's life who is a new learner in a hollow materialistic world. He works hard to learn in his job as well as in his life. He learns the various harsh reality of life and gains many pensive and pleasurable experiences which create a web of painful suffering and isolation. He conducts so many misdeeds which makes him aware of the true meaning of life and his real existence.

Arun Joshi analyses the true psych of a learner. He creates inner crises of two different ethics of idealism and pragmatism in which idealism becomes superior through the realization of inner-self. Joshi gives a universal message of peace, goodness, righteousness and to be of use. The novel ends with the awaking of Ratan's inner self who realizes the true meaning of human responsibilities and denies the values of worldly things.

\section{Works Cited}

M. Nawale, Dr. Arvind. Arun Joshi Thematic Concerns of His Novels. Authorspress, 2012.

Abraham, T.J. A Critical Study of Novels of Arun Joshi, Raja Rao and Sudhin N. Ghose. Atlantic Pub. \& Distributors, 1999.

Joshi, Arun.The Apprentice. Orient Paperbacks, 2021.

Kumar, Shankar. The Novels of Arun Joshi A Critical Study. Atlantic Pub. \& Distributors, 2003.

Sharma, Siddhartha. Arun Joshi's Novels a Critical Study. Atlantic Pub. \& Distributors, 2004.

Saleem, Abdul. Arun Joshi's Fiction Self in Exile. Creative Books, 2007.

Bhatnagar, M. K. The Novels of Arun Joshi A Critical Study. Atlantic Pub. \& Distributors, 2001.

Dwivedi, Vachaspati. The Fictional Art of Arun Joshi An Existential Perspective. Atlantic Pub. \& Distributors, 2004.

Bhatt Indira, Alexander Suja. Arun Joshi’s Fiction a Critique. Creative Books, 2001. 